\title{
DESCRIPTION OF A NEW CULEX.
}

B Y JOHN A. GROSSEECK, PATERSON, N. J .

Culex siphonalis, sp. nov.- $q$. Head brown, occiput covered with pale yellow scales; antennæ brown, basal joint and two following ones testaceous; proboscis pale brown, with dark brown scales scattered over the surface, covering the apical fourth; palpi dark brown, with minute terminal joint oval in form, pointed at the apex and slightly spiny. Mesonotum covered with pale yellow and brown scales at the sides and with a median vitta wholly of brown scales, the pale yellow scales sometimes forming a narrow border to this vitta; scutellum brown, with yellowish-brown bristles on the posterior margin; metanotum evenly brown; pleura brown, clothed with patches of dirty white scales; halteres yellowish-white, black at the apex. Abdomen blackish-brown, with pale yellowish basal bands and extremely narrow apical ones on the posterior three segments, irregularly merging into the brown, becoming diffused at the sides until beneath are mixed brown and white scales, the latter predominating. Legs with coxæ yellowish-white; femora with mixed black and white scales, wholly yellowish beneath and with a white dot at the knee; tibiæ blackish-brown, sprinkled with whitish scales ; tarsi black, except the first tarsal joint, this like the tibiæ, narrowly white banded at the base in the anterior and mid feet, save the fifth joint in the anterior one, posterior feet.broadly white banded basally; claws slender, uniserrated; wings hyaline, petiole of first submarginal cell about half as long as this cell. Length, $5 \mathrm{~mm}$.

f.-Palpi brownish, with a pale band in the centre of the basal joint and at the base of the two terminal joints. Claws all uniserrated. The bands of the abdomen very broad, mixed with brown scales and tending to cover the entire surface in the apical segments. Petiole of first submarginal cell almost as long as this cell. Length, $6 \mathrm{~mm}$. Otherwise as in the female.

This species closely resembles Culex cantans, but differs in the median thoracic stripe, the much more slender claws, its darker colour and smaller size. The larvæ are obviously different from those of cantans, possessing a very long anal siphon, which has suggested the name.

Described from two females and five males bred from larvæ collected at Livingston Park, New Jersey.

Types in the collection of the New Jersey Experiment Station, 